\title{
Keratin, Type I Cytoskeletal 14
}

National Cancer Institute

\section{Source}

National Cancer Institute. Keratin, Type I Cytoskeletal 14. NCI Thesaurus. Code C105983.

Keratin, type I cytoskeletal 14 (472 aa, $\sim 52 \mathrm{kDa}$ ) is encoded by the human KRT 14 gene.

This protein is involved in cell morphology regulation. 